\title{
Fluorine F 18 ISO-1
}

National Cancer Institute

\section{Source}

National Cancer Institute. Fluorine F18150-1. NCI Thesaurus. Code C88265.

A radioconjug ate consisting of the benzamide lig and ISO-1 labeled with the radioisotope fluorine F18 with positron-emitting radioisotope activity. Upon administration, fluorine [F18]ISO-1 binds to sigma-2 receptors, located on tumor cells, allowing visualization of sigma-2 receptor-expressing tumor cells with positron emission tomography (PET). Sigma-2 receptors, expressed in a variety of normal healthy tissues such as liver, kidneys, endocrine glands, and in the central nervous system, may be overexpressed in tumor cells. 